\title{
Compiling a high-resolution country-level ecosystem map to support environmental policy: methodological challenges and solutions from \\ Hungary
}

Eszter Tanács ${ }^{\mathrm{a} *}$, Márta Belényesi ${ }^{\mathrm{b} *}$, Róbert Lehoczkii ${ }^{\mathrm{b}}$, Róbert Pataki ${ }^{\mathrm{b}}$, Ottó

Petrik ${ }^{\mathrm{b}}$, Tibor Standovár ${ }^{\mathrm{c}}$, László Pásztor ${ }^{\mathrm{d}}$, Annamária Laborczi ${ }^{\mathrm{d}}$, Gábor

Szatmárid, Zsolt Molnára , Ákos Bede-Fazekas ${ }^{\mathrm{a}, \mathrm{f}}$, Imelda Somodi ${ }^{\mathrm{a}, \mathrm{f}}$, Dániel

Kristóf ${ }^{\mathrm{b}}$, Anikó Kovács-Hostyánszkia ${ }^{\mathrm{a}}$, Katalin Török ${ }^{\mathrm{a}}$, Lívia Kisné Fodor ${ }^{\mathrm{e}}$,

Zita Zsembery ${ }^{\mathrm{e}}$, Zoltán Friedl ${ }^{\mathrm{b}}$, Gergely Maucha ${ }^{\mathrm{b}}$

*Both authors took part equally in the preparation of the paper.

${ }^{a}$ Institute of Ecology and Botany, Centre for Ecological Research, 2163 Vácrátót, Alkotmány u. 2-4 (tanacs.eszter@ecolres.hu) Hungary

${ }^{b}$ Lechner Knowledge Centre, 1149 Budapest, Bosnyák tér 5. Hungary

${ }^{c}$ Department of Plant Systematics, Ecology and Theoretical Biology, Eötvös Loránd University, 1117 Budapest, Pázmány Péter sétány 1/C Hungary

${ }^{d}$ Institute for Soil Sciences, Centre for Agricultural Research, 1022 Budapest, Herman Ottó út 15. Hungary

${ }^{e}$ Ministry of Agriculture, Nature Conservation Department, 1052 Budapest, Apáczai Csere János utca 9. Hungary

${ }^{f}$ Centre for Ecological Research, GINOP Sustainable Ecosystems Group, H-8237

Tihany, Klebelsberg Kuno u. 3., Hungary 


\title{
Compiling a high-resolution country-level ecosystem map to support environmental policy: methodological challenges and solutions from
}

\section{Hungary}

\author{
High-resolution ecosystem maps increase the efficiency of policy \\ implementation. However due to challenges related to both data and methods, \\ such maps of appropriate scale and quality are still rarely available for \\ nationwide analyses. We present solutions to some typical challenges of national- \\ scale ecosystem mapping through the new Ecosystem Map of Hungary. It is a \\ comprehensive, spatially and thematically detailed map with a hierarchical \\ typology. The mapping methodology combined several novel elements from the \\ integration of various large-scale databases in a (theoretical) data cube to the use \\ of image-based predictive mapping (with a Random Forest classifier, using \\ Sentinel 1-2 and environmental data). A participatory method involving local \\ experts was used for validation, addressing the lack of suitable reference data as \\ well as improving map-maker - map user interaction. Besides the original \\ objective of supporting conservation-related decision-making, further uses \\ emerged from a variety of fields including spatial planning, education and \\ recreation.
}

Keywords: ecosystem mapping, national ecosystem assessment, image-based predictive mapping, ecosystem map users, participatory validation

\section{Introduction}

It is now widely recognized and stated in policy documents like the European Green Deal (EC 2019) that ecosystems provide essential services to society. However, recent reports suggest that the trends of biodiversity decline and ecosystem degradation continue with an unprecedented rate (Díaz et al. 2019), highlighting the need for action (Ruckelshaus et al. 2020). Halting the loss of biodiversity has been continuously on the agenda in the last two decades (EC 2006), yet by now it is clear that the EU is not meeting some of its most important environmental objectives for 2020 (EC 2019). Effective environmental policymaking is impossible without an up-to-date, detailed and 
reliable spatial data background (Aggestam and Mangalagiu 2020). The EU Biodiversity Strategy for 2030 (EC 2020), besides calling for action, emphasized that any action must be underpinned by sound science. The Global Assessment Report of the Intergovernmental Science-Policy Platform on Biodiversity and Ecosystem Services (IPBES 2019) also lists the better documentation of nature among the possible actions to achieve transformative change, which is key to achieving sustainability.

Ecosystem mapping is the spatial delineation of ecosystems (complex of living organisms together with their (abiotic) environment and their mutual relations) following an agreed ecosystem typology (Erhard et al. 2017). Such maps are comprehensive proxies for the spatial location of different biodiversity components and related services (Blasi et al. 2017). They are also effective tools in conveying information to decision-makers and stakeholders (Burkhard et al. 2018), therefore they are widely used in conservation management. The required minimum scale depends on the purpose, which can range from the comprehensive study of a single watershed's ecosystem services (ES) (e.g. Czúcz et al. 2018) through regional studies (e.g. Strand et al. 2018) to global estimates of the value of certain ES (e.g. Costanza et al. 2014).

Yet there is usually a cost-related trade-off between the level of (spatial and thematic) detail and the spatial extent of the mapping (Fisher et al. 2018).

The mapping and assessment of ecosystems and their services were one of the keystones of the EU Biodiversity Strategy to 2020. Action 5 of Target 2 of the Strategy required EU Member States to map and assess the ecosystems in their territory, as well as their condition, and the status and economic value of the ecosystem services they provide (Maes et al. 2013). Choosing a base map of ecosystem types is usually the first, crucial step in these national ecosystem assessments (NEAs) (Grunewald et al. 2020). CORINE Land Cover [1] (CLC; Büttner 2014) is the recommended (Erhard et al. 2017), 
and probably the most frequently used database for such tasks in Europe, although the CLC-concept is originally driven by other purposes. However, the minimum mapping unit size of 25 ha and the limited thematic resolution constrain its use in conservationrelated decision-making. A European ecosystem map of $100 \mathrm{~m}$ spatial resolution [2] (Weiss and Banko 2018) has also been produced over the past decade, representing the second level of the European Nature Information System (EUNIS) habitat classification (Davies et al. 2004). It is derived from the CLC and while it focuses more on natural habitats, it is also best suited for regional-scale assessments.

In order to address the requirements of the NEAs a variety of ecosystem maps were developed in the last decade in European Member States (e.g. Frélichová et al. 2014, Grunewald et al. 2016, Blasi et al. 2017, Nedkov et al. 2018, Černecký et al. 2020, Crouzat et al. 2019). Erhard et al. (2017) suggested a general workflow, where the basic geometry and main classes are either derived directly from satellite images or from existing land cover/land use maps. These are then refined thematically and geometrically in order to provide more policy-relevant information. There are different approaches to achieve more detail, but each has its shortcomings. One option is the integration of national sectoral databases (Černecký et al. 2020) but the availability and quality of such data may vary according to ecosystem type, leaving data gaps. Another option is the use of Potential Natural Vegetation (PNV) maps (Erhard et al. 2017, Blasi et al. 2017) for the thematic refinement of existing land cover maps. The PNV is the vegetation that 'would persist under the current conditions if it was already there' (Tüxen 1956, Somodi et al. 2012). However, while certain combinations of site characteristics make the presence of a particular habitat (and thus an ecosystem) likely, it is merely a probability (Somodi et al. 2017). A third option for refinement is the use of Earth Observation (EO) data. Such data have been successfully used for 
distinguishing vegetation-based habitat types within major physiognomic types at the site level (Burai et al. 2015, Zlinszky et al. 2012, Schuster et al. 2012). Yet their application at the national level is challenging, as the best results are achieved with datasets of high spatial (e.g. airborne laser) or radiometric (e.g. hyperspectral imagery) resolution. While prices tend to decline over time, the cost of such data is still high (Corbane et al. 2015). Data processing and acquiring the necessary ground truth data are also both resource-intensive.

The validation and accuracy assessment of the base maps used for ES assessments is of crucial importance (Foody 2015) since land use mapping error affects uncertainty in ES mapping (Dong et al. 2015). Yet the validation of national-level ecosystem maps poses a great challenge as they are often unique; differences to existing maps can simply result from the different methodology, resolution or date of origin. Although this issue has been raised, no general solution was suggested so far (Blasi et al. 2017, Černecký et al. 2019).

The Hungarian Mapping and Assessment of Ecosystem Services (MAES-HU) program was launched in 2016 within an EU-co-financed project [3] led by the Ministry of Agriculture. The first step was to create a new, comprehensive ecosystem map, which provides full spatial coverage for the country and is suitable to serve as the basis of all further assessments of ES and green infrastructure. Such a map has so far been missing.

In order to address the various needs, we combined all three methodological approaches mentioned above. The work was based mainly on already existing, regularly updated sectoral databases, whereas data gaps were filled using image-based predictive mapping (Fraser et al. 2012) with a Random Forest classifier. We combined EO data (to ensure the actuality of the map) and environmental data (for thematic enhancement). 
The aim of this paper is to provide an overview of how the typical challenges of national-level ecosystem mapping were addressed when creating the new Ecosystem Map of Hungary. The mapping methodology combines a number of novel elements from the integration of various large-scale databases in a (theoretical) data cube to the use of image-based predictive mapping for filling in data gaps. This combination of methods helps to avoid some of the usual pitfalls of the different mapping approaches. We also introduce a participatory validation method involving local experts, which, besides providing a solution for the usual lack of adequate nationwide reference data, also contributes to bridging the gap between map-makers and map-users. Finally we share some feedback from the validation experts and prospective users which reveals several possible uses of such maps within the scientific and the wider community.

\section{Material and methods}

\section{Data}

Originally the year 2015 was selected as the reference year, but it was later extended. Data from 2016 and 2017 were included as the multitemporal coverage of optical and radar imagery required for the analysis has been available countrywide only since 2017 . An important consideration was to use regularly updated datasets, which would allow the map to be continuously updated in the future. Table 1 summarizes the datasets used.

\section{Mapping method}

The data content of the new Ecosystem Map of Hungary has undergone an iterative evolutionary process. First, we had drawn an outline of the hierarchical category system based on the categories of the MAES (Maes et al. 2013), EUNIS and the Hungarian ÁNÉR (General National Habitat Classification System; Bölöni et al. 2011) systems. This was then refined repeatedly throughout the classification process according to the 
available data and methods.

Characteristics describing the Earth's surface can be divided into three main thematic groups, according to the international system developed for land monitoring (Arnold et al. 2013):

- Physical Land Cover Component (LCC);

- $\quad$ Land Use Attributes (LUA);

- Landscape Characteristics (LCH): other descriptive parameters.

Managing these components separately may be important when mapping different land surface characteristics, but it is not feasible when mapping ecosystems. Compressing all the information into a single map layer would result in a complicated and too diverse category system. Which components (and to what extent) should be involved in the definition of a category depends on the ecosystem type. In general we sought to map the current land cover to suit the planned ecosystem condition and ecosystem services assessments. Agricultural areas were however treated differently; in their case the purpose was to represent some basic types of land use (arable land, vineyards, orchards etc.). The precise separation of ecosystem types required using specific LCH elements.

We formed the methodology taking into account the recommendations of the EAGLE working group [9]. Repeatability was a very important consideration. We combined top-down and bottom-up mapping approaches (Figure 1). A map of the first, thematically least detailed hierarchical level (Level 1) was created first. The land cover layer of the Hungarian Land Parcel Identification System (LPIS) formed the basis, as it provided countrywide coverage with a high thematic and spatial resolution. Additional databases with different thematic focuses (Table 1) were used to complement it, with an 
emphasis on using self-processed EO data (Sentinel-1 and -2 images). Vector data were rasterized using pixel-centered sampling, except for most linear elements (roads, railways and waterways) where all the cells touched by the line were considered part of the element. In order to handle the various databases and integrate the results obtained with different methods, we used a data cube, which is a recent approach receiving increasing attention as a solution to store, manage, and analyse EO data (Giuliani et al. 2017, Strobl et al. 2017). The data were organized into the (theoretical) cube with uniform geometry and projection, then a set of query rules were compiled and implemented in Python (e.g. on which data layers to use, their order, threshold values etc). The final category of each pixel was automatically determined using this ruleset.

After creating the map of Level 1, further refinement into subclasses was carried out separately for each category with a methodology adjusted to the available databases. In the case of many Level 3 categories data gaps were filled by using a Random Forest (RF) learning classifier method (Breiman 2001) through iterations, similarly to the image-based predictive mapping described by Fraser et al. (2012). The RF classification was based on EO data (Sentinel-1 and -2 images), spectral indices, topographic indices and soil parameters (see Table 1). The base data set and the training data set were in all cases adapted to the specific classification needs of the given group of subcategories. The final map was compiled from the results of all these separate workflows using Python algorithms. The detailed technical (methodological) description of the full workflow was published along with the map [10]. Here we shortly summarize the refinement methods by Level 1 ecosystem types:

- In the case of urban areas and artificial surfaces, besides existing spatial thematic databases, RF classification played an important role in providing 
additional thematic information for subcategories (e.g. in defining urban green areas).

- The further classification of agricultural areas was based on the LPIS database, supplemented with an official vineyard database.

- The thematic refinement of grasslands and wetlands presented the greatest challenge, as there are no comprehensive thematic databases for these types. Therefore it was carried out with the RF classifier, using the available fine-scale habitat maps as training data. The result of the RF classification was subjected to a final refinement based on threshold values defined by experts.

- Forest sub-classes were created with a set of hierarchical expert rules, using descriptive data from the National Forestry Database (NFD). The rulesets for the second-level categories were formed first, based on hydrological characteristics. Third-level rulesets were mostly established based on the tree species composition of the upper canopy layer, but in a few cases further characteristics of the site were also taken into account. The RF classifier was used to find additional woody pixels (not covered by NFD) and distinguish between coniferous and deciduous forest patches within compartments.

- To classify rivers and lakes, the corresponding categories of the LPIS were used. Other open water surfaces found by the RF classifier complemented the results.

\section{Validation methods}

Firstly, we performed technical verification, a well-automated method, including but not limited to checking the spatial coverage, projection, cell size, data gaps and other inaccuracies. Next we checked the thematic accuracy (identifying random or systematic errors in spatial delineation, identification of thematic classes, coding etc). Choosing the right method for this needed some consideration. Firstly, the number of independent 
spatial databases suitable for comparing thematic content was limited as most of these had already been used in the creation process as training data for the Random Forest classifier. Secondly, differences between the new map and the existing ones in terms of definitions, geometrical and thematic resolution made the interpretation of the validation results difficult. Thus the thematic validation was carried out in three independent assessments (see Figure 2 and Table 2).

The first pillar of thematic validation was performed for the categories of grasslands and other herbaceous vegetation (3) and wetlands (5), where the RF classifier played a major role in the refinement. These ecosystem types were checked using the Landscape Ecological Vegetation Database \& Map of Hungary (MÉTA), completed in 2006. This database uses the Á-NÉR category system and contains areal proportions of habitat types within approx. 35-ha hexagons (Molnár et al. 2007, Horváth et al. 2008). In order to make comparison possible, crosswalks were created between the Á-NÉR and the categories of the new ecosystem map and then habitat proportions were defined for the hexagons based on the new map. The habitat proportions of the original MÉTA were then compared in 4056 hexagons to those of the new map using Bray-Curtis distances (Bray and Curtis 1957). Despite the efforts to eliminate differences in geometric and thematic resolution, these and the significant mismatch in the reference years (2004 vs 2015) caused this validation process to be indicative only.

The second pillar was based on the engagement of local experts from National Park Directorates (NPD), familiar with the habitats of their NPD's operation area. We used a project-adapted version of the "Look and Feel" method (Büttner 2012). Each expert covered the area belonging to their NPD. Within these, the specific places to be checked were selected by the expert, but participants were explicitly asked not to focus solely on Natura 2000 or other legally protected areas. $100-150$ points per area were 
recorded in a GIS database. The points were examined together with their immediate surroundings. Experts also reviewed the mapping quality in general and separately for all ecosystem types within their area. Results were used to complete a further refinement of the Ecosystem Map. All remarks were considered, the reported misclassifications examined and, where possible, corrected. However, local corrections of non-systematic misclassifications were carried out only in a limited number. Where corrections were not possible (e.g. the error is due to the characteristics of the underlying databases), the cause of the errors was described and explanations included in the documentation. The conservation experts partaking in the validation process were also asked to summarize possibilities of the professional application of the Ecosystem Map during their daily work or when addressing special tasks.

The third pillar and last step of the thematic validation was a systematic quantitative accuracy assessment (Congalton 2001), performed on the final version of the map using a photo-interpretation method developed for the verification of Copernicus land cover mapping. The Laco-Wiki online validation tool (See et al. 2015) provided the technical background, and the visual interpretation was supported by orthophotos (2015), Google and Bing images and thematic sublayers. The ecosystem types were aggregated in 20 categories in order to make them meaningful for visual interpretation. 100 points were sampled per aggregated category, but the most extensive categories like forests and arable lands had 300-500 samples.

\section{Feedback from prospective users}

Before downloading the map, prospective users are asked to provide the general purpose for which they plan to use the data (both by marking pre-defined broad categories and a short description). One person could choose more than one category, but multiple downloads from the same user in the same category were counted as one. 
We present feedback covering the 6-month period from the publication of the map in November 2019 to mid-May 2020.

\section{Results}

\section{The map}

The final typology is hierarchical with three levels; six main categories at the first level and 56 at the most detailed third level (Table 3). The main categories (Level 1) correspond to the MAES level 2 types with a few adjustments. MAES categories not present in the country (e.g. marine ecosystems) or those that occur in very small areas (e.g. sparsely vegetated land) were omitted. Shrublands were included with the forests. The main categories are as follows:

- Urban areas (1) are the most modified ecosystems, where the natural surface is partly (suburban areas with gardens, urban green areas, parks) or completely (transport networks, city centres, industrial and commercial areas) covered with artificial surfaces. Degraded areas such as mines, rubbish dumps, landfills and construction sites, are also included.

- Croplands (2) consist of land under agricultural use, including arable lands, vineyards, orchards, energy plantations and their complex mosaics (but forests are a separate category). No distinction was made based on the type of crop or the momentary state (e.g. temporarily bare surface).

- Grasslands and other herbaceous vegetation (3) cover natural and semi-natural grasslands, meadows, pastures and areas covered with other herbaceous vegetation. Halophytic habitats are included, but other grasslands temporarily affected by water belong to the wetlands.

- Forests and woodlands (4) contain all the areas registered in the NFD including clear-cuts and regenerating areas. Other wooded lands (such as forest strips, 
spontaneously reforested patches, shrublands, etc.) were included as a subcategory, „Other ligneous vegetation, woodlands (4600)”.

- Wetlands (5) include all ecosystems where the groundwater reaches the soil surface at least once a year, such as swamp woodlands, the tall-herb vegetation of marshes and fens standing in water and most wet grasslands.

- Water surfaces (6) include lakes (standing water) and rivers. Water surfaces covered with floating or shallowly rooted annual aquatic communities may occur within the category because their distinction was not possible without field survey data. Vegetation rooted in the river- and waterbeds is not included.

The digital version of the map is freely available for download as a $20 \mathrm{~m}$ resolution raster, spatially fitted to European databases [11]. The common spatial reference system is ETRS1989 LAEA (EPSG: 3035) but it can also be downloaded in the Hungarian Unified National projection system (HD72, EPSG: 23700).

Figure 3 shows examples of some localities, along with corresponding samples of CLC 2018 in order to demonstrate the differences in thematic and spatial resolution. Requests for additional information were addressed in the form of separate data layers, which can be overlaid with the Ecosystem Map for further detail. Three of these (height-based tree-shrub distinction, 4th-level forest categories and urban green vegetation) were published along with the map.

\section{Validation results}

The comparison of the grassland and wetland categories of the Ecosystem Map to the MÉTA database showed the highest match for the categories salt steppes and meadows (3200), and tall-herb vegetation of marshes and fens standing in water (5110), while the weakest correspondence was experienced in the case of the two types of open rocky grasslands (categories 3310 and 3320). As mentioned before, this validation process is 
considered indicative only.

As a result of the "Look and Feel" method, feedback from 1678 sampling points was sent back by 12 experts. According to the feedback from the validators, 'the classifications are mostly in line with the category definitions', 'there are fewer classification errors in areas poorer in natural vegetation', 'the map is almost completely accurate at a 1:25000 scale', 'the country-wide separation of natural grasslands and intensively cultivated areas at such a fine scale represents a valuable source of information'. However, at a finer scale, imperfections are more apparent. Besides clear classification errors, problems like the precision of category boundaries, handling of mosaic areas and ecosystem types, and conceptual issues (such as the classification of certain saline areas: wetland or halophytic grassland) were mentioned most. In the case of forests, a recurring critique was the omission of rare, usually small habitat types due to using the NFD units (Figure 4). The classification issues of forest clearings, infertile areas, and the under-representation of rocky grasslands were also mentioned in several feedbacks.

The systematic accuracy assessment performed on the finalized Ecosystem Map showed that the overall accuracy (calculated using an area weighted formula) for the aggregated categories was high, $97.4 \underline{3} \%$. The map also performed well in terms of user's accuracy, as the lowest value was $84.6 \%$. 15 categories out of 20 performed above $90 \%$, of which 13 categories were above 95\%. Producer's accuracy was calculated using an area-weighting methodology. Three categories out of 20 performed below $80 \%$ (swamp woodlands, high buildings and green urban areas with trees), but 12 categories above $90 \%$ of which 8 categories were above $95 \%$ (Table 4 ).

\section{Feedback on possible applications}

According to the feedback from the experts partaking in the validation, the map can be 
well used in coarse-scale habitat mapping, and it can be further refined using other, local databases and expert knowledge. It can be used for preliminary search when trying to identify the habitats of certain species. Several experts mentioned that if the map was updated at regular intervals, there would be a number of much-needed additional applications, such as monitoring the changes of surface cover on a finer scale than CLC (e.g. changes in waterlogged areas, the distribution of clearcuts in forest areas or nonnative tree-dominated forests).

The map has already been used for a variety of purposes within MAES-HU, e.g. for mapping ecosystem condition and services as well as for work on green infrastructure. As for other (potential) uses, Figure 5 shows the distribution of the answers from the downloaders according to the broad categories in the examined period. Not considering the miscellaneous Missing/Other category, the 3 most popular fields of planned application were nature conservation, research and education. Concerning the first two, much of the planned use is in some way related to species distribution mapping (either in research or in conservation planning). Some interesting applications include planning (personal) hike routes, mushroom gathering and a smartphone application for fishermen. Many of the non-professional downloaders were just interested in looking at their local environment. Feedback came from all levels of education, planned uses ranging from demonstration and exercises in primary and secondary school (in biology and geography) to use in degree works in higher education.

\section{Discussion}

\section{Classification}

The final, hierarchical classification, which is unique to the map, was based on the categories of the MAES, EUNIS and the Hungarian Á-NÉR systems, as a result of an 
iterative process. Several such systems exist already, even at the European level, e.g. the already mentioned hierarchical EUNIS, the Classification of habitat types according to the Annex I to Directive 92/43/EEC (EC 2013) and the MAES classification proposed for the assessment of ecosystem services (Maes et al. 2013), which in practice corresponds to the first level of EUNIS. The ideal design of such a system is goal- and scale-dependent. The maps on which the ES assessments are based are expected to be detailed at least at the level of MAES level 2 categories. An important choice had to be made between using an international classification, thus enabling the map to be directly connected to other European maps and databases, and between using the local classification, which is familiar to prospective users and already embedded in local decision-making processes. EUNIS was only later extended to include EasternEuropean habitats, which caused some bias, and the categories were often ambiguous (Bölöni et al. 2007) therefore we ruled out its use at the finer levels (Level 2 and 3). The typology at these finer levels tried to approximate more that of Á-NÉR.

\section{Methodological considerations}

Our method firstly relied on adapting and integrating data from spatially detailed sectoral databases. It was a major consideration that the method should allow regular updates. Sectoral thematic databases like the LPIS on land parcels or the NFD on forests are used for everyday management purposes and are thus kept up-to-date and accurate. However, as they were created for a different purpose, some of the uncertainties and errors of the ecosystem map can be attributed to the basic characteristics (e.g. the size of the spatial units - see Fig. 3) of these databases.

Data gaps, most concerning in the case of grasslands and wetlands, were filled with an image-based predictive mapping method (Fraser et al. 2012) integrating EO data with site information (soil maps and topographical information derived from a 
Digital Elevation Model, DEM), using a RF classifier. Classifying images in discrete classes in itself results in a loss of information in places where the transition of the vegetation assemblages is continuous (Rocchini et al. 2013). When using remote sensing data for ecosystem mapping, strong inter- and intra-annual variability may also affect the result to a great extent (Perennou et al. 2018), especially in the case of wetlands (Thamaga et al. 2021). In such cases, the boundaries are usually drawn based on data from a longer period using multitemporal satellite imagery (e.g. Reschke and Hüttich 2014, Inglada et al. 2017). We chose the new satellite missions of ESA, the Sentinels, as the main source of EO data, as they have high spectral and spatial resolution as well as short revisit time (Stratoulias et al 2015). The drawback of this decision was that the available time series were still short at the time (Table 5, Figure 6), which may have affected the accuracy of distinguishing certain ecosystem types (e.g. wetlands).

As available data are usually not homogeneously detailed across habitat types, different solutions are used to complement these. In Italy the CLC information was enhanced by means of compositional, ecological and biogeographical features associated with PNV types (Blasi et al. 2017). PNV was also used as a stable core input dataset of the European Ecosystem Type map (Weiss and Banko 2018). However, the presence of a certain habitat in a particular place is merely a probability, even if the combination of local site characteristics makes it likely. Even in a completely natural landscape, there is a level of stochasticity in which potentially suitable vegetation type will be actually present in a certain location (Somodi et al. 2017). Furthermore, human transformation may lead to habitats becoming so degraded that the original vegetation type would be unrecognisable. Using PNV to complete the map in such situations may lead to a distorted picture. However, for those habitat groups (grasslands, wetlands) 
where the desired thematic resolution could not have been reached otherwise, environmental data needed to be included in the RF modelling. Such methods have been successfully used in vegetation mapping in recent years (Barrett et al. 2016, Chignell et al. 2018). The image-based predictive mapping directly combined the EO data representing actuality and the site information representing potential at a fine scale, thus improving the accuracy of the RF classification while keeping potentiality to a minimum level.

\section{Lessons from the validation}

It is not easy to find a good basis for comparison concerning the results of our quality assessments - as other similar projects seem also to struggle with validation (Blasi et al. 2017, Černecký et al. 2020). The validation of large-scale ecosystem maps usually consists of designating smaller study areas, which are then mapped by experts and accuracy is defined by comparing these field maps to the ecosystem map (e.g. Černecký et al. 2020).

In order to solve the issue of the lack of suitable reference data and get a picture on the accuracy of the map we involved local experts directly in the validation process. This participatory method provided information on both the reliability of the ecosystem map and the possible causes of uncertainty. The map was found to be most precise in agricultural areas, due to the very accurate LPIS database. The slightly lower accuracies of the other categories could be attributed to several factors:

- technical and thematic errors and inaccuracies of the input and reference data (including data gaps),

- distortions due to differences of spatial or thematic resolution in the course of data integration, 
- differences in the requirements for the thematic resolution of a countrywide, sector-specific input dataset and an ecosystem map,

- uncertainties originating from the predictive mapping,

- temporal differences between the map and the reference data,

- recognisability during visual interpretation.

The factors we identified as affecting our classification results correspond to the findings of others. Lecours (2017) identified four similar 'vectors of map variability' that need to be considered when producing habitat maps: methodology, data quality, scale, and data selection.

Map-maker map-user interaction is identified as one of the bottlenecks in ES mapping processes (Palomo et al. 2018). Lecours (2017) argues that a lack of understanding of uncertainty and errors in habitat mapping can lead decision-makers to disqualify such maps. In the case of EO-based ecosystem (or habitat) mapping in particular, experts are often sceptical and need to be convinced that classification results are suitable for conservation purposes (Lucas et al. 2015). Involving the experts (some of them potential future users) in a participatory process in our case worked towards a better general understanding of the strengths and limitations of the map.

\section{Uses of ecosystem type maps}

Although some issues and a series of further possibilities and directions of development were identified in the course of the validation process, the map was found suitable to serve as a basis for various ecosystem condition and service assessments as well as green infrastructure development. At the regional and national level, it provides a new, thematically and spatially more detailed alternative for analyses which until now mostly

relied on the European CLC database. Yet according to the feedback from future users, 
possible applications are far more diverse. Some of the answers reflect potential uses related to the recent increase in the number of GIS mobile applications (Nowak et al. 2020), which usually apply thematic maps as base layers. Although there is little feedback yet about how much of these planned uses are actually realized, the available data show that the Ecosystem Map has diverse application possibilities across a wide audience.

\section{Conclusions}

As the loss of biodiversity is being recognized as one of the most serious recent challenges, the importance of high-quality up-to-date information on ecosystems is increasing. In order to provide a sound basis for national-level conservation policy decisions, we created a new, spatially and thematically detailed, comprehensive ecosystem map for Hungary, based mainly on regularly updated sectoral and EO data.

Conservation-related policy decisions increasingly depend on appropriate spatial information on the ecosystems and their services therefore it is imperative to produce detailed and accurate ecosystem maps, which can form the basis of such assessments. These should be easily and quickly repeatable in order to enable monitoring, which is best ensured through the integration of already existing, regularly updated sectoral or other databases. Methods used for filling in data gaps, especially those based on remote sensing techniques should ideally be complemented with targeted field data collection in order to ensure homogeneous, high quality training and reference data. Introducing a certain level of potentiality to the mapping is very hard to avoid, but PNV should be used with caution.

Ecosystem maps compiled from different databases have varying effective spatial resolution and accuracy, and consequently varying levels of uncertainty. As these are inherited by all further assessments based on these maps, clear communication 
of the strengths and limitations is essential. Relying on local experts in the validation process involves some of the potential future users directly in the creation of the map. Besides getting around the lack of suitable nationwide reference data and providing valuable feedback for further development, it also provides first-hand experience of the new database to potential users. Thus the process contributes to bridging the oftenlamented gap between map-makers and users. According to our findings from the feedback of downloaders, this is especially important, as such maps can now be expected to be used for a wide range of purposes beyond ES-assessments, even in the everyday life of the wider society.

\section{Acknowledgements}

The map was created in the frames of the EU co-financed project „Strategic Assessments supporting the long term conservation of natural values of community interest as well as the national implementation of the EU Biodiversity Strategy to 2020" (KEHOP-4.3.0-VEKOP-152016-00001). The program is financed by the European Regional Development Fund as part of the Széchenyi 2020 Development Program and implemented within the framework of the Environmental and Energy Efficiency Operational Program. The writing process was supported by the Hungarian Scientific Research Fund (OTKA/134329 and OTKA/135252). We would like to express our thanks especially for the work of the experts participating in the validation of the map and their contribution to the final methodology.

\section{Data availability statement}

The ecosystem map of Hungary is publicly available and (after filling in a short questionnaire) downloadable at the project homepage [3] along with detailed results of the validation process and answers to the validators' comments. A very detailed documentation of the process is available at the project website (currently in Hungarian but translation to English is in progress). The raw data of the validation and feedback from the prospective users are available on request from the corresponding author (E.T.) after anonymization. Please note that the validators and most of the prospective users providing answers were Hungarian so most of their answers are in that language. 


\section{References}

[1] Corine Land Cover database

https://land.copernicus.eu/pan-european/corine-land-cover

[2] EUNIS-based ecosystem map of Europe (3.1)

https://www.eea.europa.eu/data-and-maps/data/ecosystem-types-of-europe-1

[3] The project homepage

http://termeszetem.hu/en/

[4] Land Parcel Identification Scheme of Hungary

http://mepar.hu/

[5] VINGIS database

http://www.vingis.hu

[6] Copernicus High Resolution Layers, Water and Wetness

https://land.copernicus.eu/pan-european/high-resolution-layers/water-wetness

[7] DOSoReMI.hu soil database

www.dosoremi.hu

[8] Open Street Map

https://www.openstreetmap.org

[9] Eionet Action Group on land Monitoring in Europe (EAGLE).

http://land.copernicus.eu/eagle/general-information

[10] Detailed documentation of the Ecosystem Map of Hungary (in Hungarian)

http://termeszetem.hu/hu/okoszisztema-szolgaltatasok/eddigi-eredmenyek-1

[11] The Ecosystem Map of Hungary

http://alapterkep.termeszetem.hu/

Aggestam F, Mangalagiu D. 2020. Is sharing truly caring? Environmental data value chains and policymaking in Europe and Central Asia. Environmental Science \& Policy. 114:152-161.

Arnold S, Kosztra B, Banko G, Smith G, Hazeu G, Bock M, Valcarcel Sanz N. 2013. The EAGLE concept - A vision of a future European Land Monitoring Framework. In: Proceedings 33th EARSeL Symposium towards Horizon. Vol. 2013. [place unknown]: Citeseer; p. 551-568. 
Barrett B, Raab C, Cawkwell F, Green S. 2016. Upland vegetation mapping using Random Forests with optical and radar satellite data. Remote Sensing in Ecology and Conservation. 2(4):212-231.

Blasi C, Capotorti G, Alós Ortí MM, Anzellotti I, Attorre F, Azzella MM, Carli E, Copiz R, Garfî V, Manes F, et al. 2017. Ecosystem mapping for the implementation of the European Biodiversity Strategy at the national level: The case of Italy. Environmental Science \& Policy. 78:173-184.

Böhner J, Selige T. 2006. Spatial prediction of soil attributes using terrain analysis and climate regionalisation. In: Böhner, J., McCloy, K. R., Strobl, J., editors. SAGA - Analysis and Modelling Applications. Göttingen: Goettinger Geographische Abhandlungen; p. 13-28.

Böhner J, Conrad O. SAGA-GIS Module Library Documentation (v2.2.3) [Internet]. [accessed $2021 \mathrm{Jul}$ 14]. http://www.saga-gis.org/saga_tool_doc/2.2.3/index.html Bölöni J, Molnár Z, Illyés E, Kun A. 2007. A new habitat classification and manual for standardized habitat mapping. Annali di Botanica [Internet]. [accessed $2020 \mathrm{Jul}$ 6] 7(0). https://ojs.uniroma1.it/index.php/Annalidibotanica/article/view/9085

Bölöni J, Molnár Z, Kun A. 2011. Magyarország élőhelyei. A hazai vegetációtípusok leírása és határozója. [Habitats of Hungary. A description of Hungarian habitats]. Vácrátót, MTA ÖBKI.

Bray J, Curtis J. 1957. An ordination of upland forest communities of southern Wisconsin. Ecological Monographs. 27:325-349.

Breiman L. 2001. Random forests. Machine learning. 45(1):5-32.

Burai P, Deák B, Valkó O, Tomor T. 2015. Classification of Herbaceous Vegetation Using Airborne Hyperspectral Imagery. Remote Sensing. 7(2):2046-2066.

Burkhard B, Santos-Martin F, Nedkov S, Maes J. 2018. An operational framework for integrated Mapping and Assessment of Ecosystems and their Services (MAES). One Ecosystem 3 (2018).

Büttner G. 2012. Guidelines for verification and enhancement of high resolution layers produced under GMES initial operations (GIO) Land monitoring 2011-2013. [place unknown].

Büttner G. 2014. CORINE land cover and land cover change products. In: Land use and land cover mapping in Europe. Springer; p. 55-74. 
Černecký J, Gajdoš P, Špulerová J, Halada L', Mederly P, Ulrych L, Ďuricová V, Švajda J, Černecká L, Andráš P, Rybanič R. 2020. Ecosystems in Slovakia. Journal of Maps. 16(2):28-35.

Chignell SM, Luizza MW, Skach S, Young NE, Evangelista PH. 2018. An integrative modeling approach to mapping wetlands and riparian areas in a heterogeneous Rocky Mountain watershed. Remote Sensing in Ecology and Conservation. 4(2):150-165.

Congalton RG. 2001. Accuracy assessment and validation of remotely sensed and other spatial information. Int J Wildland Fire. 10(4):321-328.

Corbane C, Lang S, Pipkins K, Alleaume S, Deshayes M, García Millán VE, Strasser T, Vanden Borre J, Toon S, Michael F. 2015. Remote sensing for mapping natural habitats and their conservation status - New opportunities and challenges. International Journal of Applied Earth Observation and Geoinformation. 37:716.

Costanza R, de Groot R, Sutton P, van der Ploeg S, Anderson SJ, Kubiszewski I, Farber S, Turner RK. 2014. Changes in the global value of ecosystem services. Global Environmental Change. 26:152-158. https://doi.org/10.1016/j.gloenvcha.2014.04.002

Crouzat E, Zawada M, Grigulis K, Lavorel S. 2019. Design and implementation of a national ecosystem assessment - insights from the French mountain systems' experience. Ecosystems and People. 15(1):288-302.

Csonka B, Mikus G, Martinovich L, László I, Csornai G, Tikasz L, Kocsis A, Bognár E, Szekeres Á, Tóth GL, et al. 2011. Introduction of two GIS-based applications supporting area-based agricultural subsidies in Hungary (LPIS and VINGIS). In: Land quality and land use information in the European Union. Luxembourg: Publications Office of the European Union; p. 233-245.

Davies CE, Moss D, Hill MO. 2014. EUNIS Habitat Classification Revised 2004. Delegido J, Verrelst J, Alonso L, Moreno J. 2011. Evaluation of Sentinel-2 Red-Edge Bands for Empirical Estimation of Green LAI and Chlorophyll Content. Sensors. 11(7):7063-7081. https://doi.org/10.3390/s110707063

Diek S, Fornallaz F, Schaepman ME, De Jong R. 2017. Barest Pixel Composite for Agricultural Areas Using Landsat Time Series. Remote Sensing. 9(12):1245. https://doi.org/10.3390/rs9121245 
Díaz S, Settele J, Brondízio ES, Ngo HT, Agard J, Arneth A, Balvanera P, Brauman KA, Butchart SHM, Chan KMA, et al. 2019. Pervasive human-driven decline of life on Earth points to the need for transformative change. Science [Internet]. [accessed 2021 Aug 16] 366(6471). https://doi.org/10.1126/science.aax3100

Dong M, Bryan BA, Connor JD, Nolan M, Gao L. 2015. Land use mapping error introduces strongly-localised, scale-dependent uncertainty into land use and ecosystem services modelling. Ecosystem Services. 15:63-74.

EC 2006. Communication from the Commission. Halting the Loss of Biodiversity by 2010 and Beyond: Sustaining Ecosystem Services for Human Well-Being. Commission of the European Communities.

EC 2013. Interpretation manual of European Union habitats - EUR28. Eur Comm, DG Environ, 144.

EC 2019. The European Green Deal. Communication from the Commission to the European Parliament, The European Council, The Council, The European Economic And Social Committee And The Committee Of The Regions COM/2019/640 final https://eur-lex.europa.eu/legalcontent/EN/TXT/?qid=1588580774040\&uri=CELEX:52019DC0640

EC 2020. EU Biodiversity Strategy for 2030 Bringing nature back into our lives. Communication from the Commission to the European Parliament, the Council, the European Economic and Social Committee and the Committee of the Regions COM/2020/380 final. https://eur-lex.europa.eu/legalcontent/EN/TXT/?qid=1590574123338\&uri=CELEX\%3A52020DC0380

Erhard M, Banko G, Malak DA, Martin FS. 2017. Mapping ecosystem types and conditions. In: Mapping ecosystem services [Internet]. Sofia: Pensoft Publishers; p. 75-81. https://ab.pensoft.net/article/12837/download/pdf/

Fisher JRB, Acosta EA, Dennedy-Frank PJ, Kroeger T, Boucher TM. 2018. Impact of satellite imagery spatial resolution on land use classification accuracy and modeled water quality. Remote Sensing in Ecology and Conservation. 4(2):137149.

Foody GM. 2015. Valuing map validation: The need for rigorous land cover map accuracy assessment in economic valuations of ecosystem services. Ecological Economics. 111:23-28. 
Fraser R, McLennan D, Ponomarenko S, Olthof I. 2012. Image-based predictive ecosystem mapping in Canadian arctic parks. International Journal of Applied Earth Observation and Geoinformation. 14(1):129-138.

Frélichová J, Vačkář D, Pártl A, Loučková B, Harmáčková ZV, Lorencová E. 2014. Integrated assessment of ecosystem services in the Czech Republic. Ecosystem Services. 8:110-117.

Gao B. 1996. NDWI-A normalized difference water index for remote sensing of vegetation liquid water from space. Remote Sensing of Environment. 58(3):257266. https://doi.org/10.1016/S0034-4257(96)00067-3

Giuliani G, Chatenoux B, De Bono A, Rodila D, Richard J-P, Allenbach K, Dao H, Peduzzi P. 2017. Building an Earth Observations Data Cube: lessons learned from the Swiss Data Cube (SDC) on generating Analysis Ready Data (ARD). Big Earth Data. 1(1-2):100-117.

Grunewald K, Herold H, Marzelli S, Meinel G, Richter B, Syrbe R-U, Walz U. 2016. Assessment of ecosystem services at the national level in Germany-Illustration of the concept and the development of indicators by way of the example wood provision. Ecological Indicators. 70:181-195.

Grunewald K, Schweppe-Kraft B, Syrbe R-U, Meier S, Krüger T, Schorcht M, Walz U. 2020. Hierarchical classification system of Germany's ecosystems as basis for an ecosystem accounting - methods and first results. One Ecosystem. 5:e50648. Horváth F, Molnár Zs, Bölöni J, Pataki Zs, Polgár L, Révész A, Oláh K, Krasser D, Illyés E. 2008. Fact sheet of the MÉTA database 1.2. Acta Botanica Hungarica. 50(Supplement 1):11-34.

Inglada J, Vincent A, Arias M, Tardy B, Morin D, Rodes I. 2017. Operational High Resolution Land Cover Map Production at the Country Scale Using Satellite Image Time Series. Remote Sensing. 9(1):95.

IPBES. 2019. Global assessment report of the Intergovernmental Science-Policy Platform on Biodiversity and Ecosystem Services. Bonn, Germany: IPBES secretariat.

Langanke T, Moran A, Dulleck B, Schleicher C. 2016. Copernicus Land Monitoring Service-High Resolution Layer Water and Wetness Product Specifications Document. Copernicus team at EEA.

Lecours V. 2017. On the Use of Maps and Models in Conservation and Resource Management (Warning: Results May Vary). Front Mar Sci [Internet]. [accessed 
2021 Jan 12] 4.

https://www.frontiersin.org/articles/10.3389/fmars.2017.00288/full

Lee J-S, Pottier E, editors. 2017. Polarimetric Radar Imaging: From Basics to Applications. Boca Raton: CRC Press. https://doi.org/10.1201/9781420054989

Lucas R, Blonda P, Bunting P, Jones G, Inglada J, Arias M, Kosmidou V, Petrou ZI, Manakos I, Adamo M, et al. 2015. The Earth Observation Data for Habitat Monitoring (EODHaM) system. International Journal of Applied Earth Observation and Geoinformation. 37:17-28.

Maes J, Teller A, Erhard M, Liquete C, Braat L, Berry P, Egoh B, Puydarrieux P, Fiorina C, Santos F, others. 2013. An analytical framework for ecosystem assessments under action 5 of the EU biodiversity strategy to 2020. Publications office of the European Union: Luxembourg.

McFeeters SK. 1996. The use of the Normalized Difference Water Index (NDWI) in the delineation of open water features. International Journal of Remote Sensing. 17(7):1425-1432. https://doi.org/10.1080/01431169608948714

Merzlyak MN, Gitelson AA, Chivkunova OB, Rakitin VY. 1999. Non-destructive optical detection of pigment changes during leaf senescence and fruit ripening. Physiologia Plantarum. 106(1):135-141. https://doi.org/10.1034/j.13993054.1999.106119.x

Molnár Z, Bartha S, Seregélyes T, Illyés E, Botta-Dukát Z, Tímár G, Horváth F, Révész A, Kun A, Bölöni J, et al. 2007. A grid-based, satellite-image supported, multiattributed vegetation mapping method (MÉTA). Folia Geobot. 42(3):225-247.

Naszádos A. Szekeres Á. Tüske T. 2017. A MePAR felszínborítási adatának leírása. A 2015. és 2016. évi kezdő MePAR-ban szereplő felszínborítási kategóriák, valamint a felszínborítási adathoz köthető egyéb jelzések leírása. [Description of the land cover data of the Hungarian LPIS]. Budapest Főváros Kormányhivatala

Nedkov S, Borisova B, Koulov B, Zhiyanski M, Bratanova-Doncheva S, Nikolova M, Kroumova J. 2018. Towards integrated mapping and assessment of ecosystems and their services in Bulgaria: The Central Balkan case study. OE. 3:e25428.

Nowak MM, Dziób K, Ludwisiak Ł, Chmiel J. 2020. Mobile GIS applications for environmental field surveys: A state of the art. Global Ecology and Conservation. 23:e01089. 
Palomo I, Willemen L, Drakou E, Burkhard B, Crossman N, Bellamy C, Burkhard K, Campagne CS, Dangol A, Franke J, et al. 2018. Practical solutions for bottlenecks in ecosystem services mapping. One Ecosystem. 3:e20713.

Pásztor L, Laborczi A, Takács K, Szatmári G, Bakacsi Z, Szabó J. 2018. DOSoReMI as the national implementation of GlobalSoilMap for the territory of Hungary. Proceedings of the Global Soil Map 2017 Conference, July 4-6, 2017, Moscow, Russia.:17-22.

Perennou C, Guelmami A, Paganini M, Philipson P, Poulin B, Strauch A, Tottrup C, Truckenbrodt J, Geijzendorffer IR. 2018. Chapter Six - Mapping Mediterranean Wetlands With Remote Sensing: A Good-Looking Map Is Not Always a Good Map. In: Bohan DA, Dumbrell AJ, Woodward G, Jackson M, editors. Advances in Ecological Research [Internet]. Vol. 58. [place unknown]: Academic Press; [accessed 2020 Jun 23]; p. 243-277. http://www.sciencedirect.com/science/article/pii/S0065250417300272

Reschke J, Hüttich C. 2014. Continuous field mapping of Mediterranean wetlands using sub-pixel spectral signatures and multi-temporal Landsat data. International Journal of Applied Earth Observation and Geoinformation. 28:220-229.

Rikimaru A, Roy PS, Miyatake S. 2002. Tropical forest cover density mapping. Tropical Ecology. 43(1):39-47.

Rocchini D, Foody GM, Nagendra H, Ricotta C, Anand M, He KS, Amici V, Kleinschmit B, Förster M, Schmidtlein S, et al. 2013. Uncertainty in ecosystem mapping by remote sensing. Computers \& Geosciences. 50:128-135.

Rouse JW, Haas RH, Scheel JA, Deering DW. 1974. Monitoring Vegetation Systems in the Great Plains with ERTS. Proceedings of the 3rd Earth Resource Technology Satellite (ERTS) Symposium, vol. 1, p. 48-62. https://ntrs.nasa.gov/citations/19740022614

Ruckelshaus MH, Jackson ST, Mooney HA, Jacobs KL, Kassam K-AS, Arroyo MTK, Báldi A, Bartuska AM, Boyd J, Joppa LN, et al. 2020. The IPBES Global Assessment: Pathways to Action. Trends in Ecology \& Evolution. 35(5):407414.

Schuster C, Schmidt T, Conrad C, Kleinschmit B, Förster M. 2015. Grassland habitat mapping by intra-annual time series analysis - Comparison of RapidEye and TerraSAR-X satellite data. International Journal of Applied Earth Observation and Geoinformation. 34:25-34. 
See L, Perger C, Hofer M, Weichselbaum J, Dresel C, Fritz S. 2015. LACO-WIKI: An Open Access online portal for land cover validation. ISPRS Ann Photogramm Remote Sens Spatial Inf Sci. II-3/W5:167-171.

Somodi I, Molnár Z, Czúcz B, Bede-Fazekas Á, Bölöni J, Pásztor L, Laborczi A, Zimmermann NE. 2017. Implementation and application of multiple potential natural vegetation models - a case study of Hungary. Journal of Vegetation Science. 28(6):1260-1269.

Somodi I, Molnár Z, Ewald J. 2012. Towards a more transparent use of the potential natural vegetation concept - an answer to Chiarucci et al. Journal of Vegetation Science. 23(3):590-595.

Strand J, Soares-Filho B, Costa MH, Oliveira U, Ribeiro SC, Pires GF, Oliveira A, Rajão R, May P, van der Hoff R, et al. 2018. Spatially explicit valuation of the Brazilian Amazon Forest's Ecosystem Services. Nat Sustain. 1(11):657-664. https://doi.org/10.1038/s41893-018-0175-0

Stratoulias D, Balzter H, Sykioti O, Zlinszky A, Tóth VR. 2015. Evaluating Sentinel-2 for Lakeshore Habitat Mapping Based on Airborne Hyperspectral Data. Sensors. 15(9):22956-22969.

Strobl P, Baumann P, Lewis A, Szantoi Z, Killough B, Purss M, Craglia M, Nativi S, Held A, Dhu T. 2017. The six faces of the data cube. In: Proceedings of the Conference on Big Data from Space (BiDS'17). Toulouse, France; p. 28-30.

Surek Gy, Nádor G, Friedl Z, Gyimesi B, Rada M, Gera DÁ, Hubik I, Kulcsár A, Török C. 2016. Application of Radar and Optical Images to Create Copernicus High Resolution Layers: Case Studies in Hungary. 740:177.

Takács G, Molnár Z. 2009. National biodiversity monitoring system XI. Habitat mapping (2nd modified ed, p 54), Ministry of Environment and Water, Budapest.

Thamaga KH, Dube T, Shoko C. 2021. Advances in satellite remote sensing of the wetland ecosystems in Sub-Saharan Africa. Geocarto International. 0(0):1-23. https://doi.org/10.1080/10106049.2021.1926552

Tobisch T, Kottek P. 2013. Forestry-related databases of the Hungarian forestry directorate. National Food Chain Safety Office (NFCSO), [accessed 2020 Jun 23].

https://portal.nebih.gov.hu/documents/10182/862096/Forestry_related_databases .pdf/3ff92716-2301-4894-a724-72fafca9d4fc 
Török K, Fodor L, editors. 2006. Élóhelyek, mohák és gombák. Results of the Hungarian Biodiversity Monitoring System. 1. Budapest. KvVM TVH

Tüxen R. 1956. Die Heutige Potentielle Natürliche Vegetation als Gegenstand der Vegetationskartierung. Angewandte Pflanzensoziologie.(13):4-42.

Weiss M, Banko G. 2018. Ecosystem Type Map v3. 1-Terrestrial and Marine Ecosystems. European Environment Agency (EEA)—European Topic Centre on Biological Diversity.:79.

Zlinszky A, Mücke W, Lehner H, Briese C, Pfeifer N. 2012. Categorizing Wetland Vegetation by Airborne Laser Scanning on Lake Balaton and Kis-Balaton, Hungary. Remote Sensing. 4(6):1617-1650.

\section{Tables and figures}

Table 1. The most important datasets used as input for the mapping

\begin{tabular}{|c|c|c|c|}
\hline Dataset & Details & Purpose & Reference \\
\hline $\begin{array}{l}\text { Hungarian Land } \\
\text { Parcel Identification } \\
\text { System (LPIS) [4] - } \\
2015 \text { and 2016 }\end{array}$ & $\begin{array}{l}\text { Land cover } \\
\text { information and } \\
\text { thematic layers } \\
\text { including visibly } \\
\text { saline surfaces, } \\
\text { agricultural land } \\
\text { affected by excess } \\
\text { water, golf courses } \\
\text { and airports }\end{array}$ & Basis for the mapping & $\begin{array}{l}\text { Naszádos et al. } \\
2017 \\
\text { Csonka et al. } \\
2011\end{array}$ \\
\hline VINGIS [5] & & $\begin{array}{l}\text { Delineation of } \\
\text { vineyard areas }\end{array}$ & \\
\hline $\begin{array}{l}\text { National Forestry } \\
\text { Database (NFD) - } \\
2015\end{array}$ & $\begin{array}{l}\text { Tree species, site } \\
\text { information (climate, } \\
\text { soil type) }\end{array}$ & $\begin{array}{l}\text { Delineation and } \\
\text { classification of forest } \\
\text { areas }\end{array}$ & $\begin{array}{l}\text { Tobisch and } \\
\text { Kottek } 2013\end{array}$ \\
\hline $\begin{array}{l}\text { Copernicus High } \\
\text { Resolution Layer } \\
\text { (HRL), Water and } \\
\text { Wetness (WAW) for } \\
\text { the year } 2015 \text { [6] }\end{array}$ & & $\begin{array}{l}\text { Separation of wetlands } \\
\text { and grasslands }\end{array}$ & Langanke 2016 \\
\hline $\begin{array}{l}\text { Digital, Optimized, } \\
\text { Soil Related Maps and } \\
\text { Information in } \\
\text { Hungary } \\
\text { (DOSoReMI.hu) [7] }\end{array}$ & $\begin{array}{l}\text { Electrical } \\
\text { conductivity (dS/m), } \\
\text { sand, silt and clay } \\
\text { fraction }(\%), \mathrm{pH} \text { and } \\
\text { organic matter }\end{array}$ & $\begin{array}{l}\text { Input to the RF } \\
\text { classifier for wetlands } \\
\text { and grasslands }\end{array}$ & $\begin{array}{l}\text { Pásztor et al. } \\
2020\end{array}$ \\
\hline
\end{tabular}




\begin{tabular}{|c|c|c|c|}
\hline & $\begin{array}{l}\text { content }(\%) \text { of the } \\
\text { upper } 30 \mathrm{~cm} \text { soil } \\
\text { layer; soil depth }\end{array}$ & & \\
\hline nDSM 2015 & & $\begin{array}{l}\text { Input to the RF } \\
\text { classifier, input to } \\
\text { post-processing } \\
\text { (separation of built-up } \\
\text { areas by height) }\end{array}$ & \\
\hline DEM 2015 & & $\begin{array}{l}\text { Input to calculating } \\
\text { topographic indices } \\
\text { and input to RF } \\
\text { classifier }\end{array}$ & \\
\hline $\begin{array}{l}\text { Topographic indices } \\
\text { derived from the DEM }\end{array}$ & $\begin{array}{l}\text { SAGA Wetness } \\
\text { Index, Valley depth, } \\
\text { Multi-resolution } \\
\text { Ridge Top Flatness } \\
\text { (MRRTF), Multi- } \\
\text { resolution Valley } \\
\text { Bottom Flatness } \\
\text { (MRVBF), Terrain } \\
\text { Classification Index } \\
\text { for Lowlands (TCI } \\
\text { Low) }\end{array}$ & $\begin{array}{l}\text { Input to the RF } \\
\text { classifier for wetlands } \\
\text { and grasslands, input } \\
\text { to post-processing } \\
\text { (separation of } \\
\text { grassland subclasses) }\end{array}$ & $\begin{array}{l}\text { Böhner J, } \\
\text { Conrad O. } 2001 \\
\text { Böhner J, Selige } \\
\text { T. } 2006\end{array}$ \\
\hline $\begin{array}{l}\text { Open Street } \quad \text { Map } \\
(\text { OSM) }[8]\end{array}$ & $\begin{array}{l}\text { Settlement } \\
\text { boundaries, mines, } \\
\text { landfills, waste } \\
\text { dumps, roads and } \\
\text { railways }\end{array}$ & $\begin{array}{l}\text { Input to the refinement } \\
\text { of the urban/artificial } \\
\text { surfaces }\end{array}$ & \\
\hline $\begin{array}{l}\text { Thematic content of } \\
\text { other national } \\
\text { databases }\end{array}$ & $\begin{array}{l}\text { Settlement } \\
\text { boundaries, mines, } \\
\text { landfills, waste } \\
\text { dumps, roads and } \\
\text { railways }\end{array}$ & $\begin{array}{l}\text { Input to the refinement } \\
\text { of the urban/artificial } \\
\text { surfaces }\end{array}$ & \\
\hline $\begin{array}{l}\text { Habitat maps from } \\
\text { National Parks and } \\
\text { from the Hungarian } \\
\text { Biodiversity } \\
\text { Monitoring System } \\
(\mathrm{NBmR})\end{array}$ & Habitat category & $\begin{array}{l}\text { Training data for the } \\
\text { RF classifier }\end{array}$ & $\begin{array}{l}\text { Török and Fodor } \\
2006 \\
\text { Takács and } \\
\text { Molnár } 2009\end{array}$ \\
\hline $\begin{array}{l}\text { Sentinel optical } \\
\text { satellite images and } \\
\text { spectral indices (2017) }\end{array}$ & $\begin{array}{l}\text { Normalized } \\
\text { Difference } \\
\text { Vegetation Index, } \\
\text { (NDVI), Normalized } \\
\text { Difference Water }\end{array}$ & $\begin{array}{l}\text { Input to the RF } \\
\text { classifier (countrywide } \\
\text { mosaics also used for } \\
\text { visual inspection) }\end{array}$ & $\begin{array}{l}\text { Rouse et al. } \\
1974 \\
\text { S.K. McFeeters } \\
1996 \\
\text { Gao } 1996\end{array}$ \\
\hline
\end{tabular}




\begin{tabular}{|c|c|c|c|}
\hline & $\begin{array}{l}\text { Index (NDWI), } \\
\text { Normalized } \\
\text { Difference Moisture } \\
\text { Index (NDMI), Bare } \\
\text { Soil Index (BSI), } \\
\text { Green LAI (GLAI) } \\
\text { Plant Senescence } \\
\text { Reflectance index } \\
\text { (PSRI) }\end{array}$ & & $\begin{array}{l}\text { Diek et al., } 2017 \\
\text { Rikimaru et al., } \\
2002 \\
\text { Delegido et al. } \\
2011 \\
\text { Merzlyak et al. } \\
1999\end{array}$ \\
\hline $\begin{array}{l}\text { Sentinel radar images } \\
\text { and descriptors (2017) }\end{array}$ & $\begin{array}{l}\text { annual mean } \\
\text { anisotropy, annual } \\
\text { mean alpha, annual } \\
\text { standard deviation of } \\
\text { entropy, annual std } \\
\text { of Shannon-entropy } \\
\text { annual mean of } 12 \text {, } \\
\text { annual mean of } \\
\text { sigma0; } \\
\text { I2 and Shannon } \\
\text { entropy from one } \\
\text { spring and one } \\
\text { autumn image }\end{array}$ & $\begin{array}{l}\text { Input to the RF } \\
\text { classifier }\end{array}$ & $\begin{array}{l}\text { Lee, J.-S., \& } \\
\text { Pottier, E. } 2009 \\
\text { Surek et al. } 2016\end{array}$ \\
\hline $\begin{array}{l}\text { The official state } \\
\text { aerial ortophoto } \\
\text { database }(2015)\end{array}$ & & $\begin{array}{l}\text { Orientation and visual } \\
\text { inspection }\end{array}$ & \\
\hline
\end{tabular}

Table 2. Summary of the validation methods

\begin{tabular}{|l|l|l|l|}
\hline \multicolumn{1}{|c|}{ Method } & \multicolumn{1}{c|}{ Tool } & \multicolumn{1}{c|}{ Focus } & \multicolumn{1}{c|}{ When } \\
\hline $\begin{array}{l}\text { Comparison with the MÉTA } \\
\text { database. Statistical accuracy } \\
\text { assessment, spatial analysis. }\end{array}$ & R & $\begin{array}{l}\text { Grasslands and } \\
\text { wetlands }\end{array}$ & $\begin{array}{l}\text { Before map } \\
\text { finalization }\end{array}$ \\
\hline $\begin{array}{l}\text { Look and Feel method: visual } \\
\text { interpretation involving local } \\
\text { experts from National Park } \\
\text { Directorates. }\end{array}$ & $\begin{array}{l}\text { GIS tool and } \\
\text { validation } \\
\text { report }\end{array}$ & $\begin{array}{l}\text { Natural and semi- } \\
\text { natural ecosystems in } \\
\text { particular, other types } \\
\text { were also included but } \\
\text { with less weight }\end{array}$ & $\begin{array}{l}\text { Before map } \\
\text { finalization }\end{array}$ \\
\hline $\begin{array}{l}\text { Systematic statistical accuracy } \\
\text { assessment. Visual interpretation } \\
\text { using official state orthophoto } \\
\text { database (2015), Google and Bing } \\
\text { images and thematic sublayers. }\end{array}$ & $\begin{array}{l}\text { Laco-Wiki } \\
\text { online } \\
\text { validation tool }\end{array}$ & $\begin{array}{l}\text { All ecosystem types } \\
\text { (original types } \\
\text { aggregated in 20 } \\
\text { categories) }\end{array}$ & $\begin{array}{l}\text { After map } \\
\text { finalization }\end{array}$ \\
\hline
\end{tabular}


Table 3. The categories of the Ecosystem Map

\begin{tabular}{|c|c|c|c|c|c|}
\hline \multirow{9}{*}{1} & Level 1 & & Level 2 & & Level 3 \\
\hline & \multirow{8}{*}{ Urban } & \multirow{2}{*}{11} & \multirow{2}{*}{ Buildings } & 1110 & Low buildings \\
\hline & & & & 1120 & High buildings \\
\hline & & \multirow{3}{*}{12} & \multirow{3}{*}{ Roads and railways } & 1210 & Paved roads \\
\hline & & & & 1220 & Dirt roads \\
\hline & & & & 1230 & Railways \\
\hline & & 13 & $\begin{array}{l}\text { Other paved or } \\
\text { non-paved artificial } \\
\text { areas }\end{array}$ & 1310 & Other paved or non-paved artificial areas \\
\hline & & \multirow{2}{*}{14} & \multirow{2}{*}{ Green urban areas } & 1410 & Green urban areas with trees \\
\hline & & & & 1420 & Green urban areas without trees \\
\hline \multirow{6}{*}{2} & \multirow{6}{*}{ Croplands } & 21 & Arable land & 2100 & Arable land \\
\hline & & \multirow{3}{*}{22} & \multirow{3}{*}{ Permanent crops } & 2210 & Vineyards \\
\hline & & & & 2220 & Fruit and berry, and other plantations \\
\hline & & & & 2230 & Energy crops \\
\hline & & \multirow{2}{*}{23} & \multirow{2}{*}{$\begin{array}{l}\text { Complex } \\
\text { cultivation pattern }\end{array}$} & 2310 & $\begin{array}{l}\text { Complex cultivation patterns with scattered } \\
\text { buildings }\end{array}$ \\
\hline & & & & 2320 & $\begin{array}{llll}\begin{array}{l}\text { Complex } \\
\text { buildings }\end{array} & \text { cultivation patterns without } \\
\end{array}$ \\
\hline \multirow{7}{*}{3} & \multirow{7}{*}{$\begin{array}{l}\text { Grasslands } \\
\text { and other } \\
\text { herbaceous } \\
\text { vegetation }\end{array}$} & \multirow{2}{*}{31} & \multirow{2}{*}{ Sand steppes } & 3110 & Open sand steppes \\
\hline & & & & 3120 & Closed sand steppes \\
\hline & & 32 & $\begin{array}{l}\text { Salt steppes and } \\
\text { meadows } \\
\text { (grasslands } \\
\text { affected by } \\
\text { salinisation } \\
\text { included) }\end{array}$ & 3200 & $\begin{array}{l}\text { Salt steppes and meadows (grasslands } \\
\text { affected by salinisation included) }\end{array}$ \\
\hline & & \multirow{2}{*}{33} & \multirow{2}{*}{$\begin{array}{l}\text { Open rocky } \\
\text { grasslands }\end{array}$} & 3310 & Calcareous open rocky grasslands \\
\hline & & & & 3320 & Siliceous open rocky grasslands \\
\hline & & 34 & $\begin{array}{l}\text { Closed grasslands } \\
\text { in hills and } \\
\text { mountains or on } \\
\text { cohesive soil }\end{array}$ & 3400 & $\begin{array}{l}\text { Closed grasslands in hills and mountains or } \\
\text { on cohesive soil }\end{array}$ \\
\hline & & 35 & $\begin{array}{l}\text { Other herbaceous } \\
\text { vegetation }\end{array}$ & 3500 & Other herbaceous vegetation \\
\hline \multirow{10}{*}{4} & \multirow{10}{*}{$\begin{array}{l}\text { Forests and } \\
\text { woodlands }\end{array}$} & \multirow{10}{*}{41} & \multirow{10}{*}{$\begin{array}{l}\text { Forests without } \\
\text { excess water }\end{array}$} & 4101 & Beech forests \\
\hline & & & & 4102 & Sessile oak-hornbeam forests \\
\hline & & & & 4103 & Turkey oak forests \\
\hline & & & & 4104 & Downy oak forests \\
\hline & & & & 4105 & Scots pine stands of Western Transdanubia \\
\hline & & & & 4106 & $\begin{array}{l}\text { Deciduous stands of Western Transdanubia } \\
\text { mixed with Scots pine }\end{array}$ \\
\hline & & & & 4107 & Native poplar dominated forests \\
\hline & & & & 4108 & $\begin{array}{l}\text { Pioneer forests of hilly and mountainous } \\
\text { regions }\end{array}$ \\
\hline & & & & 4109 & Pedunculate oak-hornbeam forests \\
\hline & & & & 4110 & $\begin{array}{l}\text { Pedunculate oak forests, monospecific or } \\
\text { mixed with ash }\end{array}$ \\
\hline
\end{tabular}




\begin{tabular}{|c|c|c|c|c|c|}
\hline & & & & 4111 & $\begin{array}{l}\text { Forests dominated by other native tree } \\
\text { species }\end{array}$ \\
\hline & & & & 4112 & Other mixed deciduous forests \\
\hline & & 12 & Natural riverine & 4201 & Riverine willow-poplar woodlands \\
\hline & & 42 & (gallery) forests & 4202 & Riverine hardwood forests \\
\hline & & & & 4301 & $\begin{array}{l}\text { Pedunculate oak forests, monospecific or } \\
\text { mixed with ash }\end{array}$ \\
\hline & & & & 4302 & Alder forests \\
\hline & & & & 4303 & $\begin{array}{l}\text { Pedunculate oak-hornbeam forests (with } \\
\text { excess water) }\end{array}$ \\
\hline & & & & 4304 & Willow woods outside the floodplain \\
\hline & & 43 & Other forests with & 4305 & Poplar woods outside the floodplain \\
\hline & & & & 4306 & Birch woodland \\
\hline & & & & 4307 & Turkey oak forests with excess water \\
\hline & & & & 4308 & $\begin{array}{l}\text { Forests dominated by other native tree } \\
\text { species (with excess water) }\end{array}$ \\
\hline & & & & 4309 & $\begin{array}{l}\text { Other mixed deciduous forests with excess } \\
\text { water }\end{array}$ \\
\hline & & & & 4401 & Conifer-dominated plantations \\
\hline & & & & 4402 & Black locust-dominated mixed plantations \\
\hline & & 44 & Plantations & 4403 & $\begin{array}{l}\text { Plantations dominated by non-native poplar } \\
\text { and willow species }\end{array}$ \\
\hline & & & & 4404 & Plantations of other non-native tree species \\
\hline & & & Non-wooded areas & 4501 & Clearcut \\
\hline & & 45 & $\begin{array}{l}\text { registered as forest, } \\
\text { or areas under } \\
\text { reforestation }\end{array}$ & 4502 & Forest stand under regeneration \\
\hline & & 46 & $\begin{array}{l}\text { Other ligneous } \\
\text { vegetation, } \\
\text { woodlands }\end{array}$ & 4600 & Other ligneous vegetation, woodlands \\
\hline & & 51 & Herbaceous- & 5110 & $\begin{array}{l}\text { Tall-herb vegetation of marshes and fens } \\
\text { standing in water }\end{array}$ \\
\hline 5 & Wetlands & 31 & wetlands & 5120 & $\begin{array}{l}\text { Fens and mesotrophic wet meadows, } \\
\text { grasslands with periodic water effect }\end{array}$ \\
\hline & & 52 & $\begin{array}{l}\text { Woodland- } \\
\text { dominated } \\
\text { wetlands } \\
\end{array}$ & 5200 & Swamp woodlands \\
\hline 6 & Rivers and & 61 & Water bodies & 6100 & Water bodies \\
\hline 0 & lakes & 62 & Water courses & 6200 & Water courses \\
\hline
\end{tabular}

Table 4. The result of the systematic accuracy assessment on the aggregated categories of the Ecosystem Map

\begin{tabular}{|l|l|l|l|}
\hline Code & Name & User's accuracy & Producer's accuracy \\
\hline
\end{tabular}




\begin{tabular}{|c|c|c|c|c|c|c|c|}
\hline & & $\begin{array}{l}\text { Commission } \\
\text { error }\end{array}$ & Accuracy & CI & $\begin{array}{l}\text { Omission } \\
\text { error }\end{array}$ & Accuracy & CI \\
\hline 1110 & Low buildings & $9.0 \%$ & $91.0 \%$ & $5.6 \%$ & $18.2 \%$ & $81.8 \%$ & $7.2 \%$ \\
\hline 1120 & High buildings & $11.0 \%$ & $89.0 \%$ & $6.2 \%$ & $53.5 \%$ & $46.5 \%$ & $10.2 \%$ \\
\hline 1210 & Paved roads & $12.0 \%$ & $88.0 \%$ & $6.4 \%$ & $7.2 \%$ & $92.8 \%$ & $5.2 \%$ \\
\hline 1220 & Dirt roads & $2.0 \%$ & $98.0 \%$ & $2.8 \%$ & $5.6 \%$ & $94.4 \%$ & $4.5 \%$ \\
\hline 1230 & Railways & $4.0 \%$ & $96.0 \%$ & $3.9 \%$ & $17.2 \%$ & $82.8 \%$ & $7.5 \%$ \\
\hline 1310 & $\begin{array}{l}\text { Other paved or } \\
\text { non-paved artificial } \\
\text { areas }\end{array}$ & $14.0 \%$ & $86.0 \%$ & $6.8 \%$ & $15.8 \%$ & $84.2 \%$ & $7.6 \%$ \\
\hline 1410 & $\begin{array}{l}\text { Green urban areas } \\
\text { with trees }\end{array}$ & $15.0 \%$ & $85.0 \%$ & $7.0 \%$ & $20.7 \%$ & $79.3 \%$ & $7.9 \%$ \\
\hline 1420 & $\begin{array}{l}\text { Green urban areas } \\
\text { without trees }\end{array}$ & $10.0 \%$ & $90.0 \%$ & $4.8 \%$ & $3.1 \%$ & $96.9 \%$ & $2.8 \%$ \\
\hline 2100 & Arable land & $0.2 \%$ & $99.8 \%$ & $0.4 \%$ & $0.4 \%$ & $99.6 \%$ & $0.6 \%$ \\
\hline 2210 & Vineyards & $2.0 \%$ & $98.0 \%$ & $2.8 \%$ & $6.8 \%$ & $93.2 \%$ & $5.0 \%$ \\
\hline 2220 & $\begin{array}{l}\text { Fruit and berry, } \\
\text { and other } \\
\text { plantations }\end{array}$ & $5.0 \%$ & $95.0 \%$ & $4.3 \%$ & $0.8 \%$ & $99.2 \%$ & $1.8 \%$ \\
\hline 2230 & Energy crops & $2.0 \%$ & $98.0 \%$ & $2.8 \%$ & $10.5 \%$ & $89.5 \%$ & $6.1 \%$ \\
\hline 2300 & $\begin{array}{l}\text { Complex } \\
\text { cultivation pattern }\end{array}$ & $0.0 \%$ & $100.0 \%$ & $0.0 \%$ & $0.5 \%$ & $99.5 \%$ & $1.4 \%$ \\
\hline 3000 & $\begin{array}{l}\text { Grasslands and } \\
\text { other herbaceous } \\
\text { vegetation }\end{array}$ & $5.0 \%$ & $95.0 \%$ & $3.0 \%$ & $4.2 \%$ & $95.8 \%$ & $2.8 \%$ \\
\hline 4000 & $\begin{array}{l}\text { Forests and } \\
\text { woodlands }\end{array}$ & $1.7 \%$ & $98.3 \%$ & $1.5 \%$ & $1.8 \%$ & $98.2 \%$ & $1.5 \%$ \\
\hline 5110 & $\begin{array}{l}\text { Tall-herb } \\
\text { vegetation of } \\
\text { marshes and fens } \\
\text { standing in water }\end{array}$ & $15.4 \%$ & $84.6 \%$ & $6.2 \%$ & $0.7 \%$ & $99.3 \%$ & $1.6 \%$ \\
\hline 5120 & $\begin{array}{l}\text { Fens and } \\
\text { mesotrophic wet } \\
\text { meadows, } \\
\text { grasslands with } \\
\text { periodic water } \\
\text { effect }\end{array}$ & $5.0 \%$ & $95.0 \%$ & $4.3 \%$ & $8.6 \%$ & $91.4 \%$ & $5.4 \%$ \\
\hline 5200 & Swamp woodlands & $5.0 \%$ & $95.0 \%$ & $4.3 \%$ & $60.3 \%$ & $39.7 \%$ & $9.5 \%$ \\
\hline 6100 & Water bodies & $0.4 \%$ & $99.6 \%$ & $0.7 \%$ & $15.9 \%$ & $84.1 \%$ & $6.9 \%$ \\
\hline 6200 & Water courses & $2.5 \%$ & $97.5 \%$ & $2.4 \%$ & $2.4 \%$ & $97.6 \%$ & $3.1 \%$ \\
\hline
\end{tabular}

Table 5. The list of dates of the used optical Sentinel images per tile

\begin{tabular}{|l|l|l|l|l|l|l|l|}
\hline Tile & Date1 & Date2 & Date3 & Date4 & Date5 & Date6 & Date7 \\
\hline 33TWM & 20161212 & 20170309 & 20170329 & 20170401 & 20170620 & 20170826 & 20171015 \\
\hline 33TWN & 20170401 & 20170528 & 20170801 & 20170826 & 20171015 & & \\
\hline 33TXL & 20170329 & 20170707 & 20170826 & 20171219 & 20171224 & & \\
\hline 33TXM & 20161229 & 20170329 & 20170707 & 20170826 & & & \\
\hline 33TXN & 20161229 & 20170528 & 20170801 & 20170826 & 20171015 & 20171219 & \\
\hline 33TYL & 20161206 & 20170329 & 20170604 & 20170719 & 20170803 & 20171017 & 20171101 \\
\hline
\end{tabular}




\begin{tabular}{|l|l|l|l|l|l|l|l|}
\hline 33TYM & 20170329 & 20170707 & 20170826 & 20171015 & 20171104 & 20180408 & \\
\hline 33TYN & 20170329 & 20170528 & 20170826 & 20171015 & & & \\
\hline 33UXP & 20161229 & 20170528 & 20170831 & 20171015 & 20171104 & 20171219 & \\
\hline 33UYP & 20161229 & 20170329 & 20170528 & 20170831 & & & \\
\hline 34TCR & 20161206 & 20170316 & 20170624 & 20170803 & 20171012 & 20180420 & \\
\hline 34TCS & 20170624 & 20170719 & 20171002 & 20171226 & 20180125 & 20180130 & 20180420 \\
\hline 34TCT & 20161216 & 20170624 & 20171002 & 20171017 & 20180130 & & \\
\hline 34TDS & 20170704 & 20170803 & 20171002 & 20171012 & 20180130 & & \\
\hline 34TDT & 20170515 & 20170704 & 20170719 & 20170902 & 20171002 & & \\
\hline 34TES & 20170303 & 20170402 & 20170805 & 20170830 & 20171019 & 20180219 & \\
\hline 34TET & 20170303 & 20170402 & 20170830 & 20170914 & & & \\
\hline 34TFT & 20170303 & 20170402 & 20170830 & 20170929 & & & \\
\hline 34UCU & 20161229 & 20170326 & 20170831 & 20171012 & & & \\
\hline 34UEU & 20170303 & 20170402 & 20170731 & 20170830 & & & \\
\hline 34UFU & 20170402 & 20170830 & 20170929 & & & & \\
\hline 34UDU & 20161216 & 20170719 & 20170803 & 20171012 & 20180505 & & \\
\hline
\end{tabular}


Figure 1. A graphical summary of the workflow

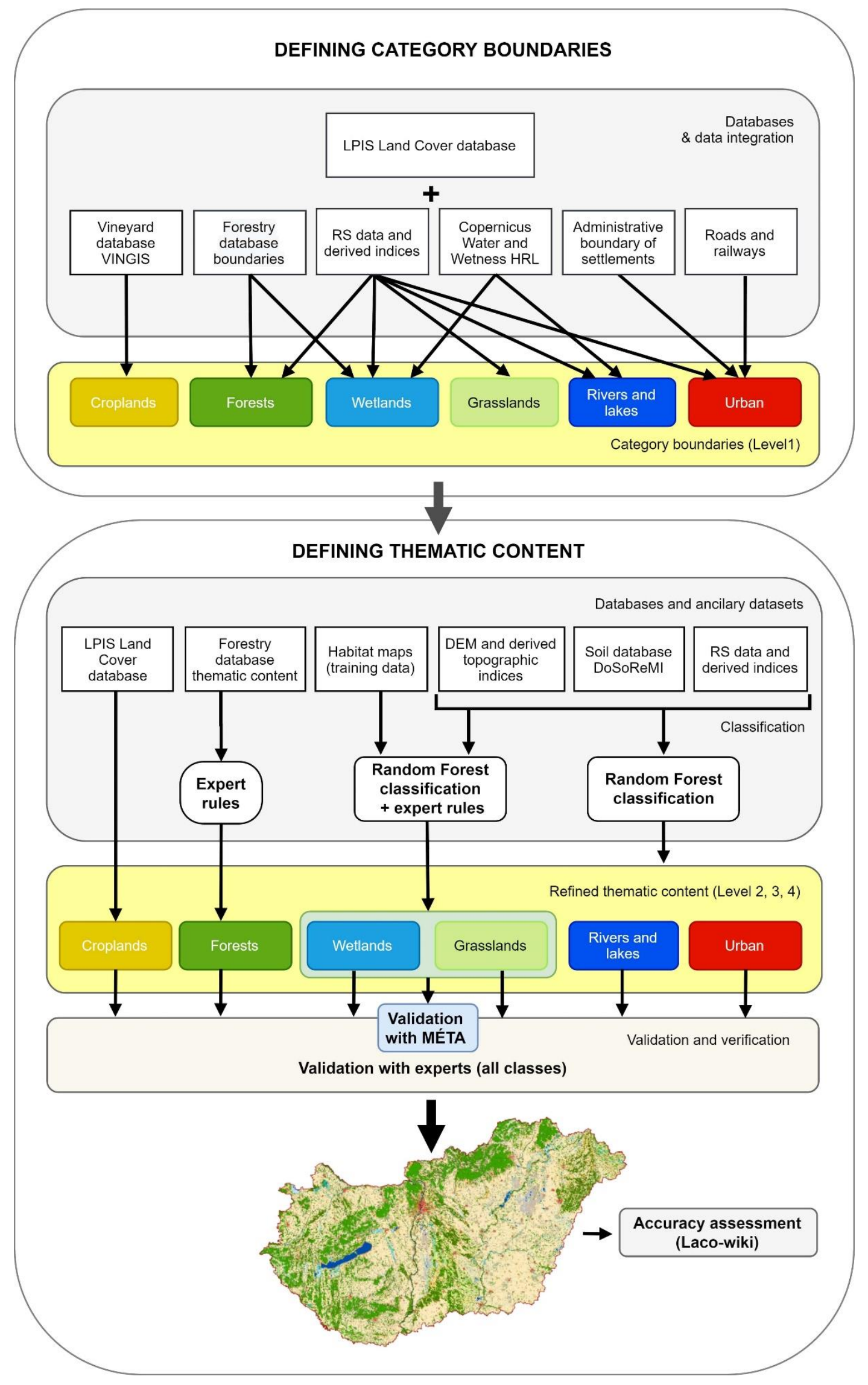


Figure 2. A graphical summary of the validation process

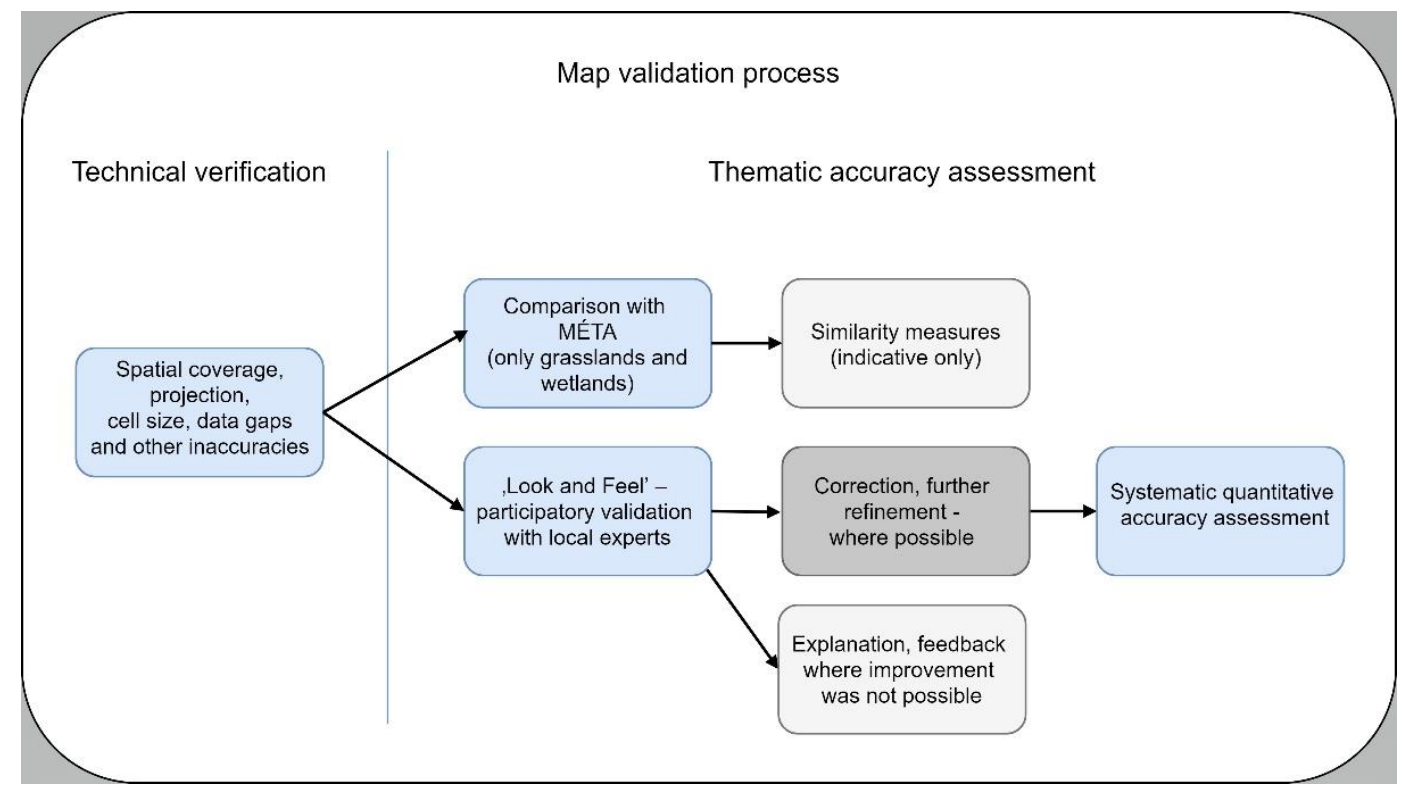

Figure 3. Comparison of CLC 2018 (left) and the Hungarian Ecosystem Map (right)

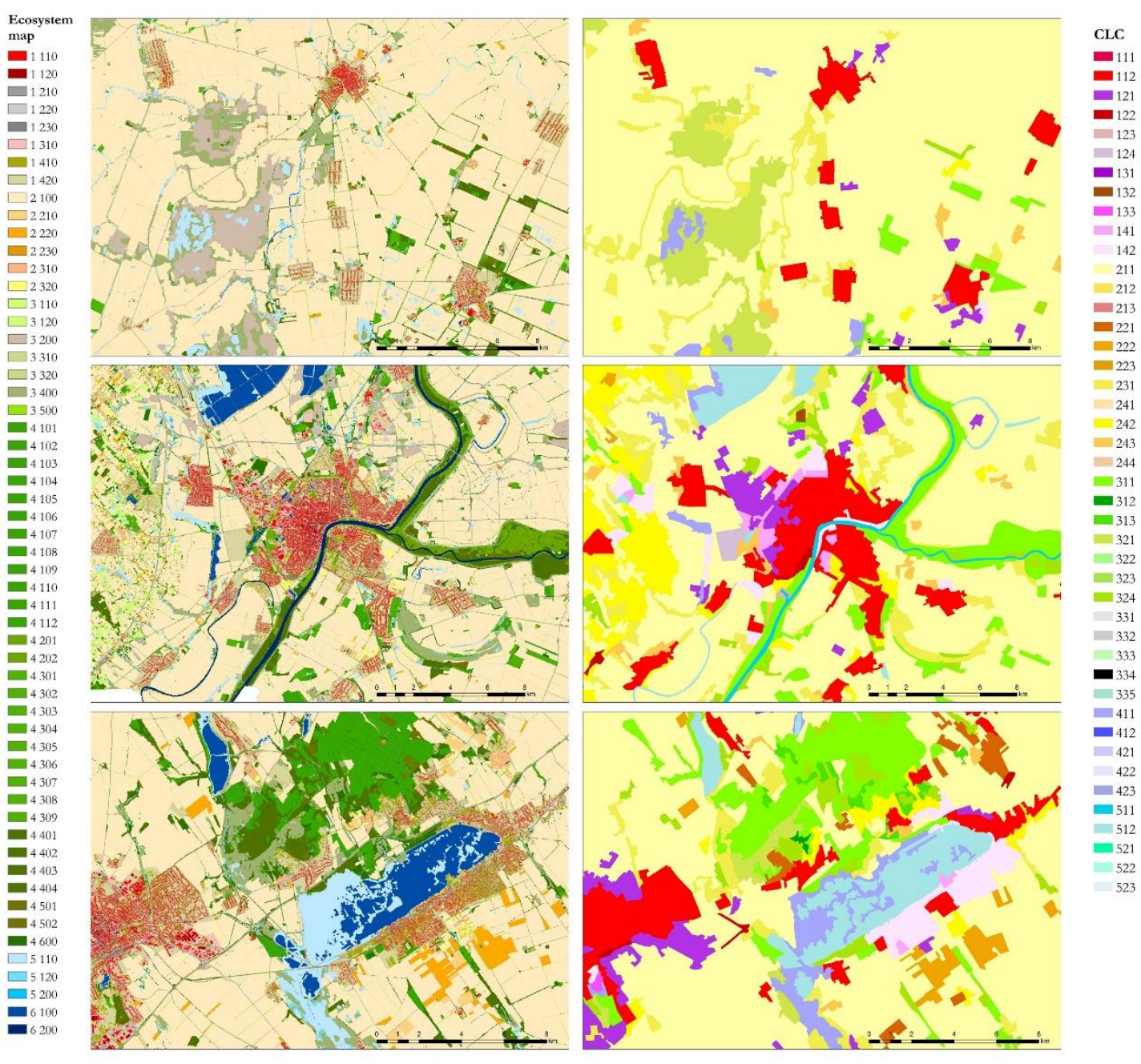


Figure 4. Comparison of forest compartment boundaries and Annex I habitat patches in a forested mountain area

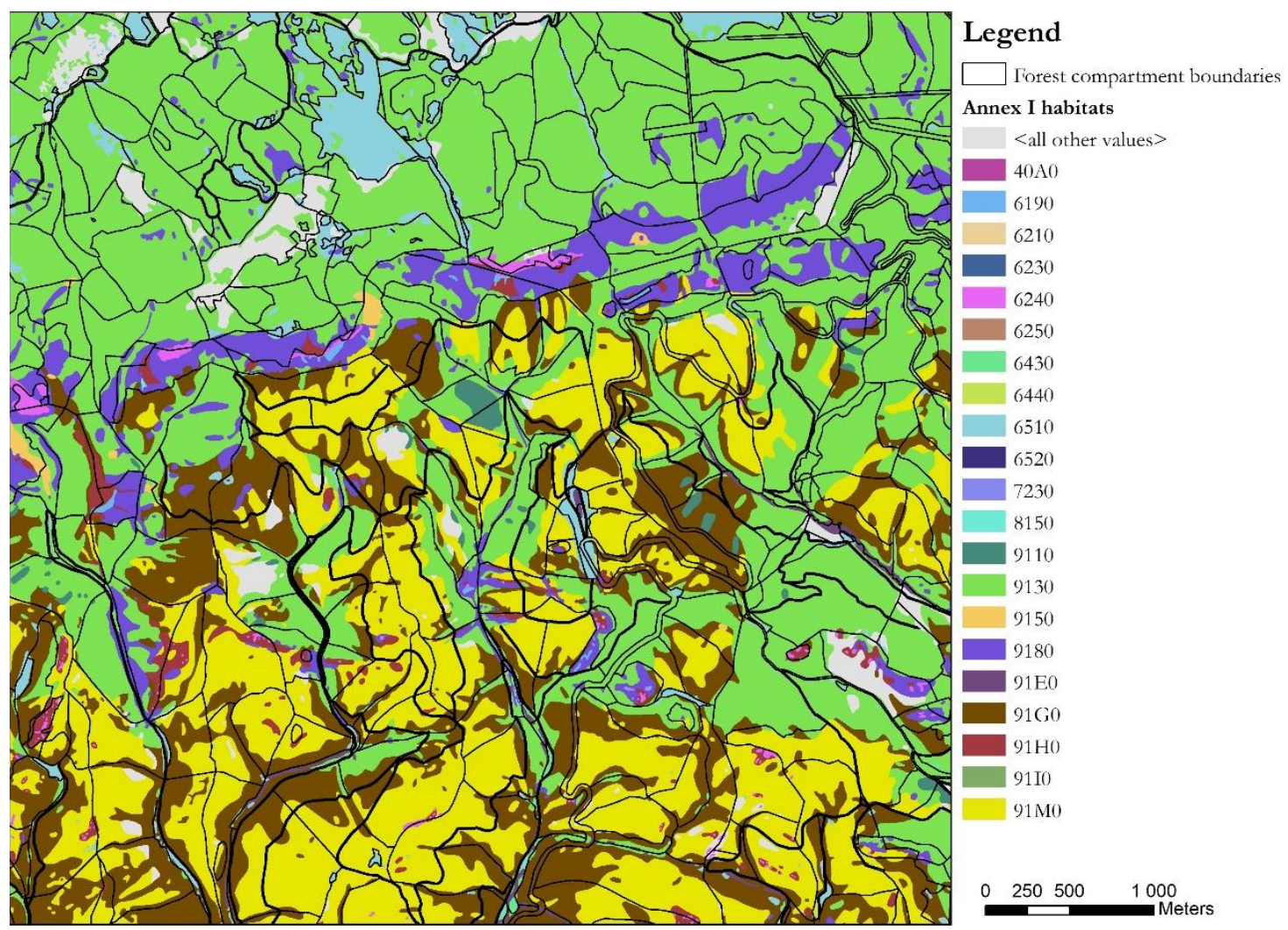


Figure 5. Number of downloads according to broad categories of prospective use

\section{Number of downloads}

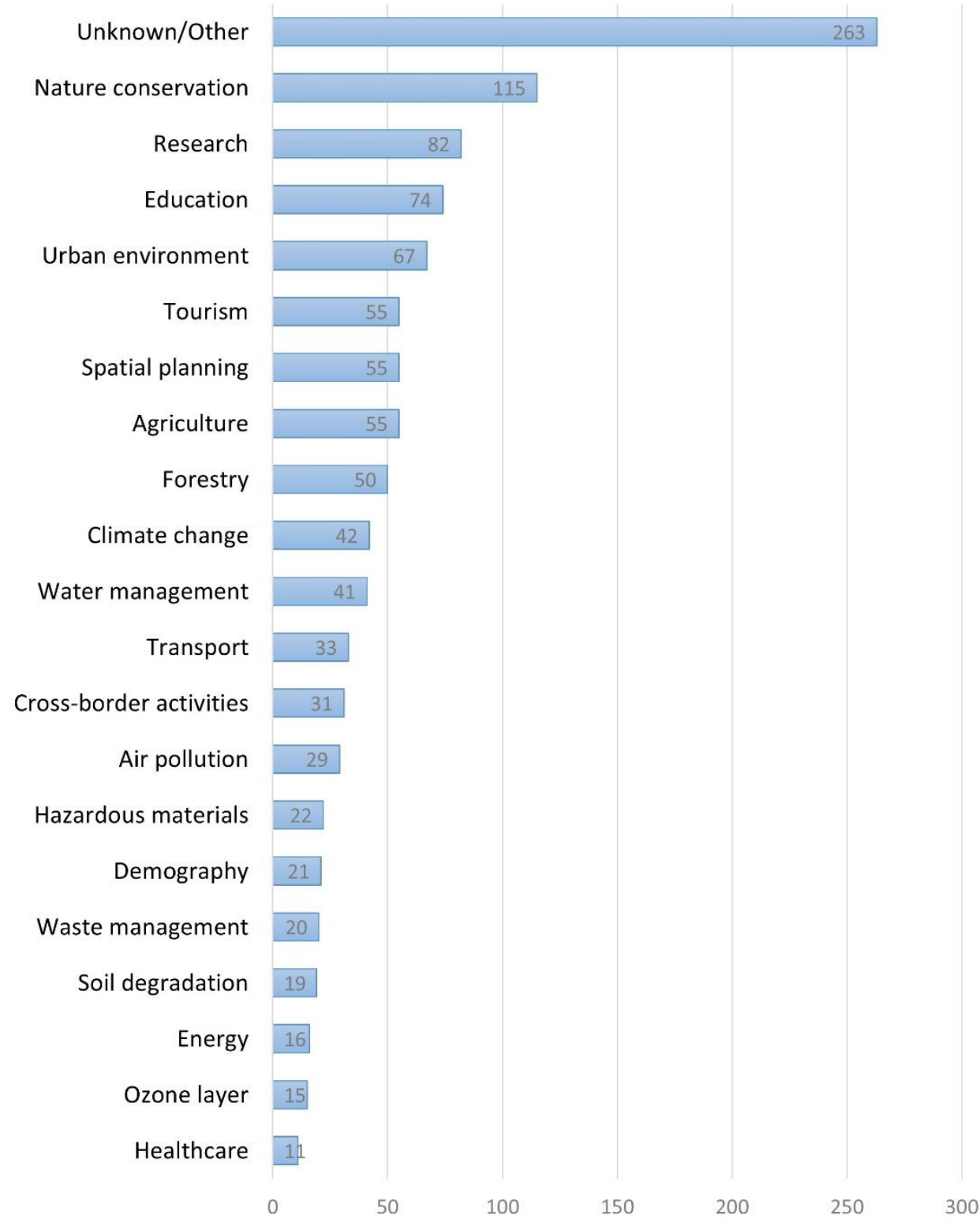


Figure 6. The map of optical Sentinel tiles used in the mapping process

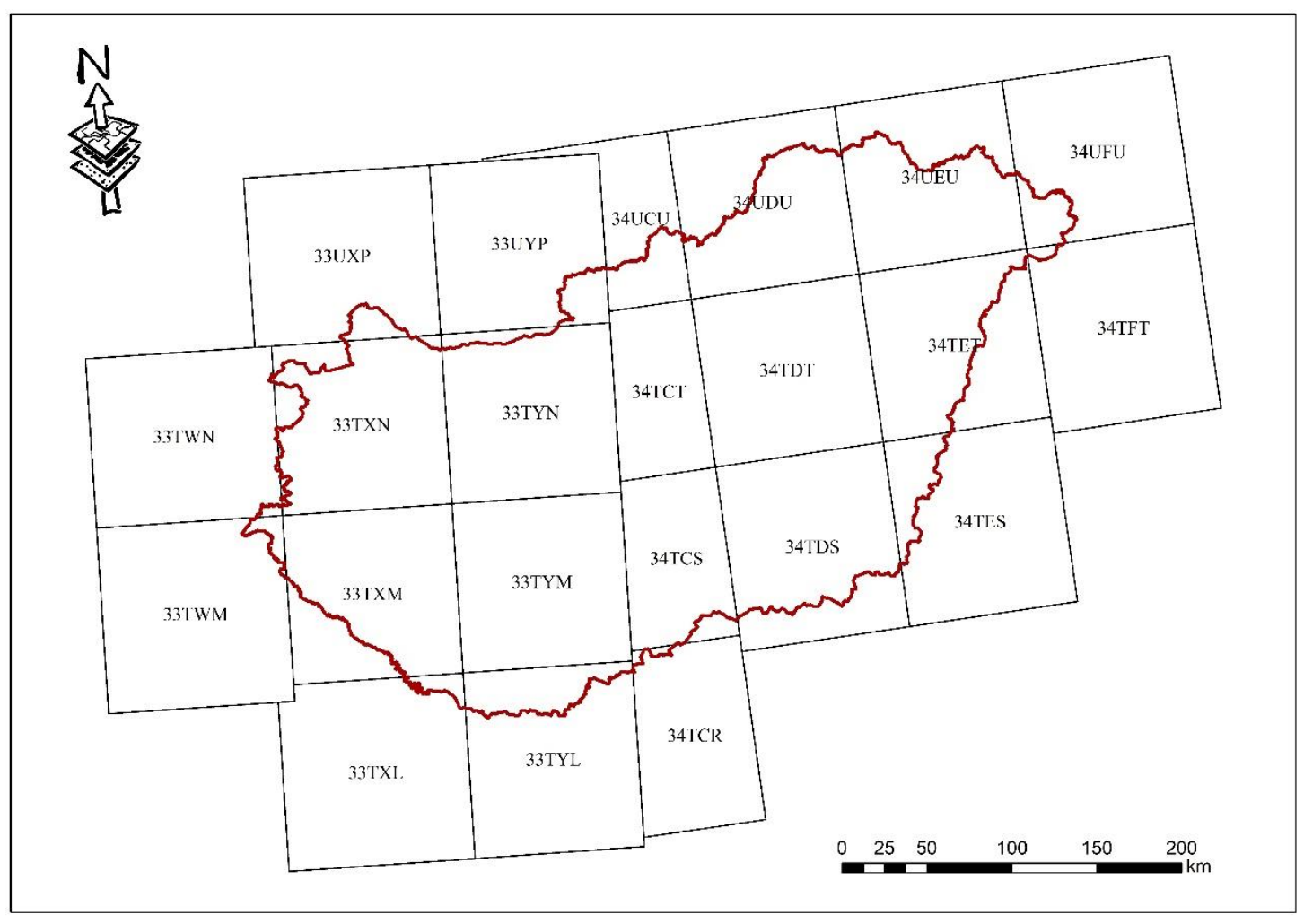

